\title{
Stem Cells Therapy in Diabetes Mellitus
}

\section{Yang $\mathrm{Xi}$ and Shizhong $\mathrm{Bu}^{*}$}

Diabetes Center, and Zhejiang Provincial Key Laboratory of Pathophysiology, Institute of Biochemistry and Molecular Biology, School of Medicine, Ningbo University, Ningbo 315211, China

\begin{abstract}
Diabetes is one of the top 10 leading causes of morbidity and mortality, affecting nearly 350 million people worldwide. $\beta$-cell replacement represents an attractive prospect for diabetes therapy but treatment options remain quite limited. There is increasing hope placed on insulin producing cells derived from human pluripotent stem cells, even as the approach faces continued challenges. The most effective protocols thus far have produced cells that express insulin, and have molecular characteristics that closely resemble genuine insulin-secreting cells. However, these cells demonstrate little sensitivity to glucose - an issue that will hopefully be resolved in coming years. This review summarizes recent progress in obtaining cells that express insulin from different progenitor sources, and highlights the major pathways and genes involved in diabetic patients.
\end{abstract}

Keywords: Stem cells; Diabetes mellitus; Cell therapy; Insulin

Abbreviations: BMSCs: Bone Marrow-derived Stem Cells; c-MYC: Myc Proto-oncogene Protein; CXCr: CXC-Chemokine Receptor; DE: Definitive Endoderm; DPP4: Dipeptidyl Peptidase 4; EB: Embryoid Body; EGF: Epidermal Growth Factor; ES: Embryonic Stem; ESCs: Embryonic Stem Cells; FACS: Fluorescence-activated Cell Sorting; FGF: Fibroblast Growth Factor; FoXa2: Forkhead Box Protein A2; GLP1: Glucagon-like Peptide 1; hESCs: Human Embryonic Stem Cells; De1: Definitive Endoderm 1; IPCs: International Programme on Chemical Safety; iPS: Induced Pluripotent Stem; KIF4: Kruppellike Factor 4; LIF: Leukemia Inhibitory Factor; LIN28: Lin-28 Homolog; MAFA: Transcription Factor MAFA; MSCs: Mesenchymal Stem Cell; Mtpn: Myotrophin; NeuroD: Neurogenic Differentiation Factor; Ngn3: Neurogenin-3; OCT: Octamer-binding Transcription Factor; Pax4: Paired Box Protein 4; Pdx1: Pancreatic and Duodenal Homeobox1; PKU: Phenylketonuria; SGLT2: Sodium-dependent Glucose Cotransporter 2; SOX2: Sry related HMG box-2; T1DM: Type 1 Diabetes Mellitus; TGF $\beta$ : Transforming Growth Factor $\beta$; TZDs: Thiazolidinediones

\section{Introduction}

Diabetes mellitus is a devastating and complex metabolic disease, expected to affect over 500 million people worldwide by the year 2030; up from 350 million in 2010 [1]. Approximately $95 \%$ of patients suffer from type 2 diabetes, and its prevalence is expected to increase in the future [2]. Furthermore, the age of onset for type 2 diabetic patients is trending toward earlier onset in adulthood [3]. Diabetes is associated with severe long-term micro- and macrovascular complications, and carries a high rate of morbidity and mortality. Indeed, both type 1 and 2 diabetes are a significant public health concern with numerous debilitating complications, leading to a constant increase in treatment costs.

Currently, both type 1 and type 2 diabetes can be treated with insulin analogues and Pramlintide. Pramlintide or Amylin is a 37-residue peptide hormone that delays gastric emptying, and endorses satiety and inhibits glucagon secretion; averting post-prandial prickles in blood glucose levels. Recombinant modifications of insulin can act faster and longer, similar to endogenous insulin [4]. The following drugs are used to treat type 2 diabetes: 1 ) Metformin, augments insulin release, 2) Sulphonylureas (Thiazolidinediones (TZDs) and Meglitinides), increase insulin sensitivity, 3) Bromocriptine, antagonizes dopamine
$\mathrm{D}_{2}$ and serotonin receptors, 4) Glucagon-like peptide 1 (GLP1) analogues, 5) Alpha-glucosidase inhibitors, 6) Dipeptidyl peptidase 4 (DPP4) inhibitors, and 7) Sodium-dependent glucose cotransporter 2 (SGLT2) inhibitors [5-11].

The physiological control of blood glucose levels can only be restored effectively by replacing the $\beta$-cell mass [12]. $\beta$-cells in the pancreatic islets of Langerhans are responsible for the production of insulin and much of the pathology of diabetes losses can be attributed to the loss of $\beta$-cell number and function $[13,14]$. In patients with type 1 diabetes, the onset of overt disease is assumed to occur when the $\beta$-cell mass falls below $20 \%$ of the normal range $[15,16]$; whereas in patients with type 2 diabetes, the $\beta$-cell mass is unable to meet the increased insulin demands of the body [17]. Eventually, the $\beta$-cell mass in type 2 diabetes also declines to $40-60 \%$ of the normal range. Indeed, in both type 1 and type 2 diabetes, restoration of a functional $\beta$-cell mass constitutes the central goal of diabetes therapy $[18,19]$. Exploring ways to protect or expand pancreatic $\beta$-cell mass and function could be an effective therapeutic approach, and $\beta$-cell replacement represents an attractive therapeutic prospect. Stem cells, particulary the pluripotent stem cells, demonstrate strong self-renewal abilities and potential to differentiate into all cell types of the body, making them a supreme cell source for regenerative medicine and tissue engineering [20-22]. In this review, we address some of the major advancements that could lead to regenerative therapy for diabetes mellitus.

\section{Human Embryonic Stem Cells}

Human embryonic stem cells (hESCs) have the ability to form cells derived from all three germ layers [23]. hESCs can be induced to differentiate into fetal-like pancreatic cells in vitro using a 33-day, 7-stage protocol [24]. The differentiation protocols for inducing hESCs

*Corresponding author: Shizhong Bu, 818 Fenghuai Rd., Jiangbei District, Ningbo 315211, China, Tel: 0086-574-87609607; Fax: 0086-574-87608638; E-mail: bushizhong@nbu.edu.cn

Received March 17, 2014; Accepted April 24, 2014; Published April 26, 2014

Citation: Xi Y, Bu S (2014) Stem Cells Therapy in Diabetes Mellitus. J Stem Cell Res Ther 4: 199. doi:10.4172/2157-7633.1000199

Copyright: $\odot 2014 \mathrm{Xi}$ Y, et al. This is an open-access article distributed under the terms of the Creative Commons Attribution License, which permits unrestricted use, distribution, and reproduction in any medium, provided the original author and source are credited. 
into $\beta$-cells involves activation of Wnt and transforming growth factor $\beta$ (TGF $\beta$ ) signaling pathways [25-27]. Fibroblast growth factor (FGF) 10 , retinoic acid and activin are used to induce the differentiation of hESCs into Pdx1 expressing cells [28-30]. Other markers used to identify definitive endoderm include SOX17, brachyury protein, FGF7, FoXa2, CXC-chemokine receptor (CXCr) 4 and Cerberus [31-35]. Definitive endoderm 1 and 2 (iDe1 and iDe2) have been shown to induce the construction of ultimate endoderm from mouse and human ESCs with about $70-80 \%$ efficiency, which is much higher than the differentiation induced by activin or nodal $[36,37]$. The next in vitro step is to reproduce the formation of the pancreatic dorsal anlage. This step is dependent on simultaneous retinoic acid signaling and inhibition of Hedgehog signaling, both of which have been effectively reproduced [38]. Activin a in conjuction with Wnt3a, as well as iDe1 and iDe2 in combination with FGF10 are capable of inducing development of endoderm cells into pancreatic progenitors in vitro [39]. Indolactam $\mathrm{V}$ activates protein kinase $\mathrm{C}$ signaling after treatment with $\mathrm{Wnt} 3 \mathrm{a}$, activin a, FGF10, cyclopamine and retinoic acid and results in induction of pancreatic progenitor cells expressing Pdx1 with close to $50 \%$ efficiency [40-42]. miR-375 has a critical role in early development since miR-375 is highly expressed in definitive endoderm and regulates expression of Mtpn and Pdk1 genes. Controlling the expression of miR-375 could also assist mature hESCs-derived $\beta$-cells $[43,44]$.

hESCs have been differentitated into cells capable of synthesizing insulin, glucagon, somatostation, pancreatic polypeptide and ghrelin [45]. Therefore, they represent a novel alternative source for targeted therapies and regenerative medicine for diabetes. One approach is derived on the similarities of pancreatic $\beta$-cells and neuroepithelial development [46]. The other approach is based on reproducing the individual sequential steps that are known in normal $\beta$-cell ontogenesis during fetal pancreatic development. The hESC cell line, PKU1.1, can be induced to differentiate into insulin-producing cells (IPCs) using both protocols [47]. Although these hESC-derived cells containing insulin are similar to that of human islets, the cells lack the main function of glucose-stimulated insulin secretion in vitro. However, hESCs have been shown to secrete insulin in response to glucose after transplantation into immune deficient mice [48]. The final stages of differentiation to derive functionally mature $\beta$-cells from hESCs must occur in vivo [49].

\section{Induced Pluripotent Stem Cells}

Embryonic stem (ES) and induced pluripotent stem (iPS) cells have potential applications in regenerative medicine for diabetes. Although iPS cells are a potential alternative to hESCs [50,51], their application is still limited in many countries. iPS cells have been engendered from mouse and human somatic cells by introducing SOX 2 combinations of Kruppel-like factor 4 (KIF4), NANOG, octamer-binding transcription factor (OCT) 4, Myc protooncogene protein (c-MYC) and lin-28 homolog a (LIN28) [52]. Usage of the oncogenes, c-MYC and KLF4, raises the uncertainty of potential tumor formation [53,54]. This risk of using reprogrammed cells has been lowered by employing valproic acid, a histone deacetylase inhibitor that enables reassemble of primary human fibroblasts with only two factors, OCT4 and SOX2 [55]. The initial use of retroviruses or lentiviruses to deliver transcription factor genes raised the chance of viral integration into the host genome increasing the risk of tumorigenicity. Novel protocols have been developed that use repeated transfection of expression plasmids in iPS cells without any evidence of plasmid integration [56]. Although current protocols for this reprogramming are developing rapidly and no longer require the use of oncogenes and viral vectors, it is unclear whether iPS cells are truly equal to hESCs with respect to pluripotency [57].

Lentiviral overexpression of the reprogramming factors OCT4, SOX2, NANOG and LIN can induce the formation of iPS cells from umbilical cord blood $[58,59]$. Due of a juvenescent cell source, umbilical cord blood use addresses some of the concerns that arise from the use of adult somatic cells, such as accumulation of mutations over the lifetime of an organism [60]. Currently available differentiation protocols generate IPCs at a very low frequency. Furthermore, due to the lack of well-distinguished pancreatic beta cell-specific cell surface markers, it is difficult to purify IPCs from a mixed cell population. One of the main reasons for this limitation is insufficient PDX1 expression in the embryoid body (EB) or definitive endoderm (DE)derived precursors [61]. However, ectopic expression of pancreatic and duodenal homeobox 1 , an essential pancreatic transcription factor, in mouse ES cells results in improved differentiation into IPCs [62]. Unfortunately, iPS cells, if produced from a type 1 diabetic patient and transplanted back into the donor, would still be targeted by the immune system. Despite their limitations, the value of IPCs lies in their ability to generate both immune cells and $\beta$-cells and the potential to expand our understanding of autoimmune destruction of $\beta$-cells.

Although much progress has been made in this area, applications in clinic are still very limited. Transplanting encapsulated pancreatic progenitors derived from hESCs into diabetic recipients is a strategy that is now being explored in the Australian Diabetes Therapy Project [63]. There are still important issues to be addressed before this treatment is widely applicable, including difficulties in maintaining insulin independence, low success rates of islet isolation, multiple donor requirements, and side effects associated with the use of immunosuppressants.

\section{Mesenchymal Stem Cells}

Mesenchymal stem cells (MSCs) have pro-angiogenic and immunomodulatory properties and the remarkable ability to expand, making them extremely attractive from a therapeutic perspective. Moreover, they are easily procurable from virtually every tissue [64]. One source of MSCs can be found in the bone marrow stroma. Bone marrow-derived stem cells (BMSCs) are an invaluable source of adult pluripotent stem cells. An early study reported that transplantation of c-kit expressing bone marrow-derived cells resulted in localization to ductal and islet structures and enhanced insulin secretion. Although occurring in low frequency, these results suggest that BMSCs have the ability to differentiate into $\beta$-cells [65]. Si found that autologous MSCs transplantation in a rat model of type 2 diabetes resulted in enhanced insulin secretion, increased islet numbers in pancreas and ameliorated insulin sensitivity, suggesting functional effects of autologous MSCs inoculum on insulin target tissues [66].

Preliminary studies have also tested the graft-promoting effects of BMSC transplantation in a cynomolgus monkey model. Allogenic BMSC transplantation significantly enhanced islet engraftment and function [67]. When human BMSCs were transplanted into NOD/scid mice with streptozotocin-induced pancreatic damage, enhanced insulin secretion and reduced hyperglycemia was observed. Interestingly, the human BMSCs mainly engrafted into the pancreas and the kidney, whereas no cells were detected in the spleen, lung or liver [68].

Since the effects of single MSC transplantation are relatively short (lasting for a period of four weeks), multiple intravenous 
transplantations were performed and efficiently restored longterm blood glucose homeostasis in streptozotocin-induced diabetic mice. Despite the induced $\beta$-cell differentiation, about fifty percent of donor cells engrafted were surrounding the central veins in liver [69]. These data provide important clues about how to develop effective antirejection therapies and the results suggest that BMSC transplantation may be useful in ameliorating insulin secretion and improving tissue repair in patients with diabetes mellitus.

Recently, clinical application of autologous MSC transplantation in type 2 diabetes patients was reported to get prospective success. Estrada performed a phase 1 study in 25 patients with combined MSC transplantation and hyperbaric oxygen treatment and they found improved metabolic variables including fasting plasma glucose, C-peptide, HbAlc and calculation of C-peptide/glucose ratio, as well as reduced insulin requirements in these patients [70]. Another clinical study revealed that autologous MSC transplantation in 10 patients efficiently reduced insulin dependence, with three patients achieving insulin independence for some time. Importantly, no serious adverse effects were reported [71]. Although the underlying mechanisms are currently unclear, BMSCs may clearly become the ideal choice in therapeutic applications for diabetes.

\section{Pancreatic Duct Cells}

Several factors have been found to promote proliferation of $\beta$-cells. Brennand et al. in 2007 demonstrated that $\beta$-cells have the ability to sustain themselves through slow replication $[72,73]$. However, the mechanism remains unclear and the numbers of new $\beta$-cells are inadequate. Almost twenty years ago, pancreatic duct cells were found to possess the ability to form new islets with $\beta$-like cells [74]. In addition, adult exocrine pancreatic cells have been changed into functional $\beta$-cells through the combination of epidermal growth factor (EGF) and leukemia inhibitory factor (LIF) in vitro [75]. It is believed that the pancreatic duct, acinus and islet are derived from pancreatic duct epithelial cells after birth. Therefore, pancreatic duct epithelial cells are assumed to represent the main source of stem cells for pancreatic regeneration.

New $\beta$-cell formation from mouse ducts has been observed under suitable conditions $[76,77]$. Several strategies have been reported to produce insulin-expressing cells or $\beta$-like cells from rodent duct cells. Important growth factors including exendin-4, glucagon-like peptide 1 (GLP1), activin A, hepatocyte growth factor and betacellulin were reported to drive induction of insulin expression in pancreatic duct cell lines [78-83]. It has also been demonstrated that induction of insulinproducing cells from pancreatic duct cells can be achieved through adenoviral-mediated gene transfer technology by expressing Pdx1, neurogenin-3 (Ngn3), neurogenic differentiation factor (NeuroD) or paired box protein 4 ( $\operatorname{Pax} 4$ ) [84]. However, these methods pose the risk of unexpected genetic modifications in target cells.

The delivery of recombinant protein into cells through protein transduction represents an effective method for the induction the $\beta$-like cells. Noguchi found that the Pdx1 protein, which plays crucial role in regulating pancreatic $\beta$-cell differentiation and insulin gene transcription, can permeate cells and perform similar functions as endogenous $\mathrm{Pdx} 1$ protein. Importantly, Pdx1 transduced pancreatic duct cells results in enhanced insulin gene transcription [85]. Recently, Kaitsuka found that protein transduction of three proteins, Pdx1, NeuroD, and transcription factor MafA (MAFA), can induce mouse ES and iPS cells into insulin-producing cells with glucose-response. When transplanted into diabetic mice, these induced insulin-producing cells have the ability to restore normoglycemia [86].

When human pancreatic duct cells were sorted using a carbohydrate antigen 19-9 antibody (CA19-9, a duct marker) and cultured under serum-free conditions, they could expand and enhance insulin transcription [87]. These observations suggested that human pancreatic duct cells could be a source of stem cells for $\beta$-cell differentiation; however, the induced cells had limited expansion and insulin secretion was not confirmed in a glucose responsive manner. Hoesli found that using a CD90 antibody to deplete fibroblast-like cells from the human pancreatic duct cells greatly improved the expansion of cells [88]. This finding suggests that obtaining pure pancreatic duct stem cells is crucial. Based on the FACS-sorted method, Lee purified human pancreatic duct cells using a CD133 antibody and found that these sorted cells could maintain ductal phenotypes by a self-renewing ability. When the transcription factors MafA, Pdx1, Pax6 and Neurog3 were co-expressed through an adenovirus-mediated transgenic system, CD133 plus cells cultured into spheres and had greatly enhanced insulin gene expression. Importantly, when transplanted into NOD scid gamma mice, the progeny of the CD133 plus cells showed insulin release in a glucose dependent manner and circulating human insulin was detected in the serum of host mice [89]. These data suggest that CD133 positive pancreatic duct cells could potentially be used in human $\beta$-cell replacement therapy if new strategies for safer expansion and differentiation are developed.

A significant amount of transdifferentiation takes place from intrahepatic biliary epithelial cells (IHBECs) through the use of certain transcriptional factors. The cells can express proteins characteristic of $\beta$-cells and secrete insulin [90,91]. Gordon Weir et al. [51] reported that the IHBECs were originally expanded using a novel collagen matrix protocol and these cells kept their biliary phenotype in culture. Ectopic expression of Pdx1, NeuroD or Pdx1-VP16, lead to $\beta$-cell genes (ins 1 and 2, PC 1 and 2) expressing the islet hormones glucagon and somatostatin. C-peptide expression was used as a biomarker to confirm $\beta$-like cells, and demonstrate the correct processing of insulin protein. $\beta$-cell functionality was proven by measuring insulin secretion in response to glucose. An interesting observation in this report was that the $\beta$-cell phenotype is only present in a sub-population of IHBECs, suggesting that not all IHBECs are able to transdifferentiate into a $\beta$-cell phenotype. This study strongly implies that it is possible to coerce the differentiation of IHBECs towards a $\beta$-cell phenotype, which supports the possibility that IHBECs have the potential to be useful for $\beta$-cell replacement therapy [92].

\section{Conclusions}

Both type 1 and type 2 diabetes are among the most amenable diseases for treatment. Functional restoration of existing $\beta$-cells, transplantation of stem cells or stem cell-derived $\beta$-like cells might provide new opportunities for treatment (Figure 1). However, the use of stem cells to generate a renewable source of $\beta$-cells for diabetes treatment remains challenging, largely due to safety concerns. Current differentiation protocols that use viral vectors to generate induced $\beta$-cells result in low numbers of functional $\beta$-cells, and possible unexpected genetic modifications. While BMSC transplantation could improve metabolic variables with no obvious side effects, Tang reported that long-term culture of human BMSCs raises the risk of malignant transformation post transplantation [93]. Safety issues, including sources of cells, must be carefully evaluated before clinical applications. The definition of stem cells depends on the cell surface 


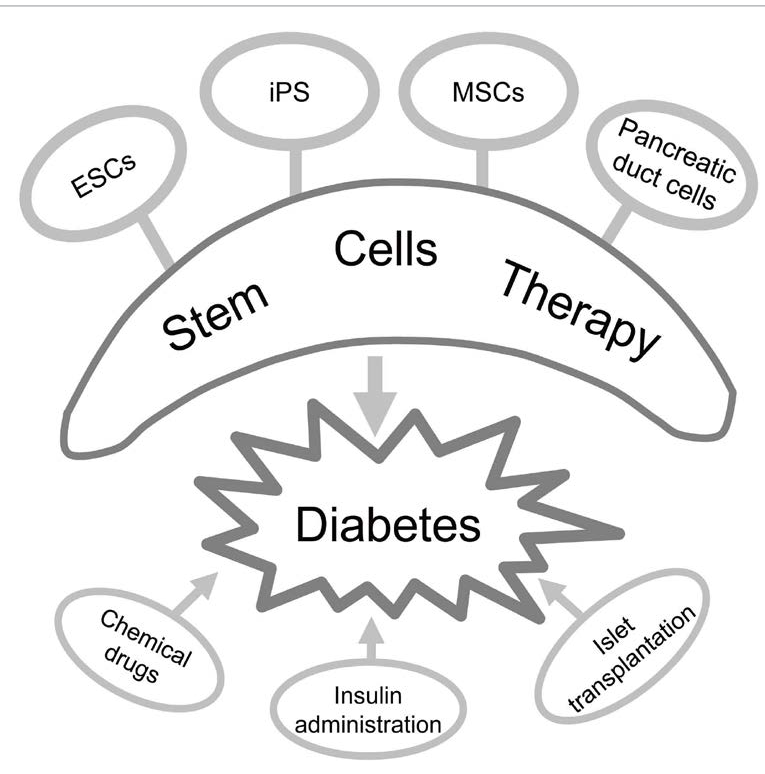

Abbreviations: ESCs, embryonic stem cells; iPS, induced pluripotent stem; MSCs, mesenchymal stem cells.

Figure 1: Treatment to diabetes.

markers, and their efficiency of differentiation greatly relies on the purity of cell source sorted by cell surface markers. Reports suggest that approximately 100,000 cells are needed for each recipient, but a low differentiation rate necessitate longer time in in vitro culture to develop adequate numbers of cells for transplantation. However, the longer culture time can increase the possibility of malignancy. Indeed, new technologies to improve differentiation efficiency are essential.

Monitoring clinical trials closely will be key. Development of a transplant registry in combination with assessment and optimization of clinical protocols will help identify optimal cell types and cell surface markers for characterization, and may ultimately lead to safe, effective treatments.

\section{Acknowledgments}

This work was supported in part by National Natural Science Foundation of China (81370165 and 31301068), Natural Science Foundation of Ningbo (2013A610207 and 2013A610209), and K.C. Wong Magna Fund in Ningbo University.

\section{References}

1. Abu-Rmeileh NM, Husseini A, Capewell S, O'Flaherty M (2013) Preventing type 2 diabetes among Palestinians: comparing five future policy scenarios. BMJ Open 3(12): e003558.[PubMed]

2. Vetere A, Choudhary A, Burns SM, Wagner BK (2014) Targeting the pancreatic $\beta$-cell to treat diabetes. Nat Rev Drug Discov 13(4): 278-289.[PubMed]

3. Power C, Thomas C (2011) Changes in BMI, duration of overweight and obesity, and glucose metabolism: 45 years of follow-up of a birth cohort. Diabetes Care 34(9):1986-1991.[PubMed]

4. El-Kaissi S, Sherbeeni S (2011) Pharmacological management of type 2 diabetes mellitus: an update. Curr Diabetes Rev 7(6): 392-405.[PubMed]

5. Odawara M, Hamada I, Suzuki M (2014) Efficacy and safety of vildagliptin as add-on to metformin in Japanese patients with type 2 diabetes mellitus. Diabetes Ther.[PubMed]

6. Kobayashi K, Yokoh H, Sato Y, Takemoto M, Uchida D, et al. (2014) Efficacy and safety of the dipeptidyl peptidase-4 inhibitor sitagliptin compared with a-glucosidase inhibitor in Japanese patients with type 2 diabetes inadequately controlled on sulfonylurea alone (SUCCESS-2): a multicenter, randomized, open-label, non-inferiority trial. Diabetes Obes Metab.[PubMed]
7. Ghosh A, Sengupta N, Sahana P, Giri D, Sengupta P, et al. (2014) Efficacy and safety of add on therapy of bromocriptine with metformin in Indian patients with type 2 diabetes mellitus: A randomized open labeled phase IV clinical trial. Indian J Pharmacol 46(1): 24-28.[PubMed]

8. Rizos EC, Ntzani EE, Papanas N, Tsimihodimos V, Mitrogianni Z, et al. (2014) Combination Therapies of DPP4 Inhibitors and GLP1 Analogues with Insulin in Type 2 Diabetic Patients: A Systematic Review. Curr Vasc Pharmacol 11(6): 992-1000.[PubMed]

9. Dabhi AS, Bhatt NR, Shah MJ (2013) Voglibose: an alpha glucosidase inhibitor.J Clin Diagn Res 7(12): 3023-3027.[PubMed]

10. Gitt AK, Bramlage P, Binz C, Krekler M, Deeg E, et al. (2013) Prognostic implications of DPP-4 inhibitor vs. sulfonylurea use on top of metformin in a real world setting - results of the 1 year follow-up of the prospective DiaRegis registry.Int J Clin Pract 67(10): 1005-1014.[PubMed]

11. Ferrannini E, Muscelli E, Frascerra S, Baldi S, Mari A, et al. (2014) Metabolic response to sodium-glucose cotransporter 2 inhibition in type 2 diabetic patients. J Clin Invest 124(2): 499-508.[PubMed]

12. Kim JJ, Kido Y, Scherer PE, White MF, Accili D (2007) Analysis of compensatory beta-cell response in mice with combined mutations of Insr and Irs2. Am J Physiol Endocrinol Metab 292(6): E1694-1701.[PubMed]

13. Butler AE, Janson J, Bonner-Weir S, Ritzel R, Rizza RA, et al. (2003) Betacell deficit and increased beta-cell apoptosis in humans with type 2 diabetes. Diabetes 52(1): 102-110.[PubMed]

14. Ferrannini $E$ (2010) The stunned beta cell: a brief history. Cell Metab 11(5): 349-352.[PubMed]

15. Butler AE, Galasso R, Meier JJ, Basu R, Rizza RA, et al (2007) Modestly increased beta cell apoptosis but no increased beta cell replication in recentonset type 1 diabetic patients who died of diabetic ketoacidosis. Diabetologia 50(11): 2323-2331.[PubMed]

16. Gepts W (1995) Pathologic anatomy of the pancreas in juvenile diabetes mellitus. Diabetes 14(10): 619-633.[PubMed]

17. American Diabetes Association (2013) Diagnosis and classification of diabetes mellitus. Diabetes Care 36 (Suppl 1): S67-74.[PubMed]

18. Malmgren S, Spégel P, Danielsson AP, Nagorny CL, Andersson L, et al. (2013) Coordinate changes in histone modifications, mRNA levels, and metabolite profiles in clonal INS-1 832/13 $\beta$-cells accompany functional adaptations to lipotoxicity. J Biol Chem 288(17): 11973-11987.[PubMed]

19. Dupuis J, Langenberg C, Prokopenko I, Saxena R, Soranzo N (2010) New genetic loci implicated in fasting glucose homeostasis and their impact on type 2 diabetes risk. Nat Genet 42(5): 105-116.[PubMed]

20. Imaizumi M, Sato Y, Yang DT, Thibeault SL (2013) In vitro epithelia differentiation of human induced pluripotent stem cells for vocal fold tissue engineering. Ann Otol Rhinol Laryngol 122(12): 737-747.[PubMed]

21. Budniatzky I, Gepstein L (2014) Concise review: reprogramming strategies for cardiovascular regenerative medicine: from induced pluripotent stem cells to direct reprogramming. Stem Cells Transl Med 3(4): 448-457.[PubMed]

22. Powers JM, Trobridge GD (2013) Identification of hematopoietic stem cell engraftment genes in gene therapy studies. J Stem Cell Res Ther 2013(Suppl 3).[PubMed]

23. Parsons XH (2014) Direct conversion of pluripotent human embryonic stem cells under defined culture conditions into human neuronal or cardiomyocyte cell therapy derivatives.Methods Mol Biol.[PubMed]

24. Bruin JE, Erener S, Vela J, Hu X, Johnson JD, et al. (2014) Characterization of polyhormonal insulin-producing cells derived in vitro from human embryonic stem cells. Stem Cell Res 12(1): 194-208.[PubMed]

25. Jagtap S, Meganathan K, Wagh V, Natarajan K, Hescheler J, et al. (2013) All-trans retinoic acid and basic fibroblast growth factor synergistically direct pluripotent human embryonic stem cells to extraembryonic lineages. Stem Cell Res 10(2): 228-240.[PubMed]

26. Payne C, King J, Hay D (2011) The role of activin/nodal and Wnt signaling in endoderm formation. Vitam Horm 85: 207-216.[PubMed]

27. Zhou J, Su P, Li D, Tsang S, Duan E, et al. (2010) High-efficiency induction of neural conversion in human ESCs and human induced pluripotent stem cells with a single chemical inhibitor of transforming growth factor beta superfamily receptors. Stem Cells 28(10):1741-1750.[PubMed] 
28. Sui L, Geens M, Sermon K, Bouwens L, Mfopou JK (2013) Role of BMP signaling in pancreatic progenitor differentiation from human embryonic stem cells. Stem Cell Rev 9(5): 569-577.[PubMed]

29. Xu X, Browning VL, Odorico JS (2011) Activin, BMP and FGF pathways cooperate to promote endoderm and pancreatic lineage cell differentiation from human embryonic stem cells. Mech Dev 128(7-10): 412-427.[PubMed]

30. Johannesson M, Ståhlberg A, Ameri J, Sand FW, Norrman K, et al. (2009) FGF4 and retinoic acid direct differentiation of hESCs into PDX1-expressing foregut endoderm in a time- and concentration-dependent manner. PLoS One 4(3): e4794.[PubMed]

31. Bhonde RR, Sheshadri $P$, Sharma S, Kumar A (2014) Making surrogate $\beta$-cells from mesenchymal stromal cells: perspectives and future endeavors. Int $\mathrm{J}$ Biochem Cell Biol 46: 90-102.[PubMed]

32. Li J, Zhu L, Qu X, Li J, Lin R, et al. (2013) Stepwise differentiation of human adipose-derived mesenchymal stem cells toward definitive endoderm and pancreatic progenitor cells by mimicking pancreatic development in vivo. Stem Cells Dev 22(10): 1576-1587.[PubMed]

33. Takizawa-Shirasawa S, Yoshie S, Yue F, Mogi A, Yokoyama T, et al. (2013) FGF7 and cell density are required for final differentiation of pancreatic amylase-positive cells from human ES cells. Cell Tissue Res 354(3): 751-759. [PubMed]

34. Li X, Yuan J, Li W, Liu S, Hua M (2014) Direct differentiation of homogeneous human adipose stem cells into functional hepatocytes by mimicking liver embryogenesis. J Cell Physiol 229(6): 801-812.[PubMed]

35. Olesnicky Killian EC, Birkholz DA, Artinger KB (2009) A role for chemokine signaling in neural crest cell migration and craniofacial development. Dev Biol 333(1): 161-172.[PubMed]

36. Taylor-Weiner H, Schwarzbauer JE, Engler AJ (2013) Defined extracellular matrix components are necessary for definitive endoderm induction. Stem Cells 31(10): 2084-2094.[PubMed]

37. Ogaki S, Shiraki N, Kume K, Kume S (2013) Wnt and Notch signals guide embryonic stem cell differentiation into the intestinal lineages. Stem Cells 31(6):1086-1096.[PubMed]

38. Frantz ED, Peixoto-Silva N, Pinheiro-Mulder A (2012) Endocrine pancreas development: effects of metabolic and intergenerational programming caused by a protein-restricted diet. Pancreas 41(1): 1-9.[PubMed]

39. Tahamtani $Y^{1}$, Azarnia $M$, Farrokhi A, Sharifi-Zarchi A, Aghdami $N$, et al. (2013) Treatment of human embryonic stem cells with different combinations of priming and inducing factors toward definitive endoderm. Stem Cells Dev 22(9): 1419-1432.[PubMed]

40. Thatava T, Nelson TJ, Edukulla R, Sakuma T, Ohmine S, et al. (2011) Indolactam V/GLP-1-mediated differentiation of human iPS cells into glucoseresponsive insulin-secreting progeny. Gene Ther 18(3): 283-293.[PubMed]

41. Chen AE, Borowiak M, Sherwood RI, Kweudjeu A, Melton DA (2013) Functional evaluation of ES cell-derived endodermal populations reveals differences between Nodal and Activin A-guided differentiation. Development 140(3): 675686.[PubMed]

42. Chen S, Borowiak M, Fox JL, Maehr R, Osafune K, et al. (2009) A smal molecule that directs differentiation of human ESCs into the pancreatic lineage. Nat Chem Biol 5(4): 258-265.[PubMed]

43. Lahmy R, Soleimani M, Sanati MH, Behmanesh M, Kouhkan F, et al. (2014) miRNA-375 promotes beta pancreatic differentiation in human induced pluripotent stem (hiPS) cells. Mol Biol Rep 41(4): 2055-2066.[PubMed]

44. Sun K, Chang X, Yin L, Li J, Zhou T, et al. (2014) Expression and DNA methylation status of microRNA-375 in patients with type 2 diabetes mellitus. Mol Med Rep 9(3): 967-972.[PubMed]

45. Cai Q, Bonfanti P, Sambathkumar R, Vanuytsel K, Vanhove J, et al. (2014) Prospectively Isolated NGN3-Expressing Progenitors From Human Embryonic Stem Cells Give Rise to Pancreatic Endocrine Cells. Stem Cells Transl Med 3(4): 489-499.[PubMed]

46. Yamada M, Terao M, Terashima T, Fujiyama T, Kawaguchi $Y$, et al. (2007) Origin of climbing fiber neurons and their developmental dependence on Ptf1a. J Neurosci 27(41): 10924-10934.[PubMed]

47. Wei R, Yang J, Hou W, Liu G, Gao M, et al. (2013) Insulin-producing cells derived from human embryonic stem cells: comparison of definitive endoderm- and nestin-positive progenitor-based differentiation strategies. PLoS One 8(8): e72513.[PubMed]

48. Li X, Romain RD, Park D, Scadden DT, Merchant JL, et al. (2014) Stress Hematopoiesis Is Regulated by the Krüppel-Like Transcription Factor ZBP-89. Stem Cells 32(3): 791-801.[PubMed]

49. Rezania A, Bruin JE, Xu J, Narayan K, Fox JK, et al. (2013) Enrichment of human embryonic stem cell-derived NKX6.1-expressing pancreatic progenitor cells accelerates the maturation of insulin-secreting cells in vivo. Stem Cells 31(11): 2432-2442.[PubMed]

50. Takahashi K, Yamanaka S (2006) Induction of pluripotent stem cells from mouse embryonic and adult fibroblast cultures by defined factors. Cell 126(4): 663-676.[PubMed]

51. Stadtfeld M, Nagaya M, Utikal J, Weir G, Hochedlinger K (2008) Induced pluripotent stem cells generated without viral integration. Science 322(5903): 945-949.[PubMed]

52. Heffernan C, Sumer H, Verma PJ (2011) Generation of clinically relevan "induced pluripotent stem" (iPS) cells. J Stem Cells 6(3):109-127.[PubMed]

53. Miyazaki S, Yamamoto H, Miyoshi N, Takahashi H, Suzuki Y, et al. (2012) Emerging methods for preparing iPS cells. Jpn J Clin Oncol 42(9): 773-779. [PubMed]

54. Lin SL, Ying SY (2013) Mechanism and method for generating tumor-free iPS cells using intronic microRNA miR-302 induction. Methods Mol Biol 936: 295312.[PubMed]

55. Huangfu D, Osafune K, Maehr R, Guo W, Eijkelenboom A, et al. (2008) Induction of pluripotent stem cells from primary human fibroblasts with only Oct4 and Sox2. Nat Biotechnol 26(11): 1269-1275.[PubMed]

56. Okita K, Nakagawa M, Hyenjong H, Ichisaka T Yamanaka S (2008) Generation of mouse induced pluripotent stem cells without viral vectors. Science 322(5903): 949-953.[PubMed]

57. Montserrat N, Garreta E, González F, Gutiérrez J, Eguizábal C, et al. (2011) Simple generation of human induced pluripotent stem cells using poly-betaamino esters as the non-viral gene delivery system. J Biol Chem 286(14): 12417-12428.[PubMed]

58. Ikeda Y, Kudva YC (2013) Human fetal pancreatic islet-like structures as source material to treat type 1 diabetes. Stem Cell Res Ther 4(6):159.[PubMed]

59. Kadam SS, Bhonde RR (2010) Islet neogenesis from the constitutively nestin expressing human umbilical cord matrix derived mesenchymal stem cells. Islets 2(2): 112-120.[PubMed]

60. Aguayo-Mazzucato C, Bonner-Weir S (2010) Stem cell therapy for type 1 diabetes mellitus. Nat Rev Endocrinol 6(3): 139-148.[PubMed]

61. Bose B, Shenoy SP, Konda S, Wangikar P (2012) Human embryonic stem cell differentiation into insulin secreting $\beta$-cells for diabetes. Cell Biol Int 36(11):1013-1020.[PubMed]

62. Raikwar SP, Zavazava N (2013) Differentiation and lineage commitment of murine embryonic stem cells into insulin producing cells. Methods Mol Biol 1029: 93-108.[PubMed]

63. Tuch B, Hughes T, Evans M (2011) Encapsulated pancreatic progenitors derived from human embryonic stem cells as a therapy for insulin-dependent diabetes. Diabetes Metab Res Rev 27: 928-932.[PubMed]

64. Antonello $P$ (2012) Mesenchymal stem cells for the treatment of diabetes Diabetes 61(6):1355-1356.[PubMed]

65. Hess D, Li L, Martin M, Sakano S, Hill D, et al. (2003) Bone marrow-derived stem cells initiate pancreatic regeneration. Nat Biotechnol 21(7): 763-770. [PubMed]

66. Si Y, Zhao Y, Hao H, Liu J, Guo Y, et al. (2012) Infusion of mesenchymal stem cells ameliorates hyperglycemia in type 2 diabetic rats: identification of a nove role in improving insulin sensitivity. Diabetes 61: 1616-1625.[PubMed]

67. Berman DM, Willman MA, Han D, Kleiner G, Kenyon NM, et al. (2010) Mesenchymal stem cells enhance allogeneic islet engraftment in nonhuman primates. Diabetes 59: 2558-2568.[PubMed]

68. Lee RH, Seo MJ, Reger RL, Spees JL, Pulin AA, et al. (2006) Multipotent stromal cells from human marrow home to and promote repair of pancreatic islets and renal glomeruli in diabetic NOD/scid mice. Proc Natl Acad Sci U S A 103(46): 17438-17443.[PubMed] 
69. Ho JH, Tseng TC, Ma WH, Ong WK, Chen YF, et al. (2012) Multiple intravenous transplantations of mesenchymal stem cells effectively restore long-term blood glucose homeostasis by hepatic engraftment and $\beta$-cell differentiation in streptozocin-induced diabetic mice. Cell Transplant 21(5): 997-1009.[PubMed]

70. Estrada EJ, Valacchi F, Nicora E, Brieva S, Esteve C, et al. (2008) Combined treatment of intrapancreatic autologous bone marrow stem cells and hyperbaric oxygen in type 2 diabetes mellitus. Cell Transplant 17(12): 1295-1304.[PubMed]

71. Bhansali A, Upreti V, Khandelwal N, Marwaha N, Gupta V, et al. (2009) Efficacy of autologous bone marrow-derived stem cell transplantation in patients with type 2 diabetes mellitus. Stem Cells Dev 18(10):1407-1416.[PubMed]

72. Brennand K, Huangfu D, Melton D (2007) All beta cellls contribute equally to islet growth and maintenance. PloS Biol 5(7): e163.[PubMed]

73. Huising MO, van der Meulen T, Vaughan JM, Matsumoto M, Donaldson CJ, et al. (2010) CRFR1 is expressed on pancreatic beta cells, promotes beta cell proliferation, and potentiates insulin secretion in a glucose-dependent manner. Proc Natl Acad Sci USA 107(2): 912-917.[PubMed]

74. Wang RN (1995) Duct- to islet-cell differentiation and islet growth in the pancreas of dunct-ligated adults rats. Diabetologia 38(12): 1405-1411.[PubMed]

75. Baeyens L, De Breuck S, Lardon J, Mfopou JK, Rooman I, et al. (2005) In vitro generation of insulin-producing beta cells from adult exocrine pancreatic cells. Diabetologia 48:49-57.[PubMed]

76. Inada A, Nienaber C, Katsuta H, Fujitani Y, Levine J, et al. (2008) Carbonic anhydrase II-positive pancreatic cells are progenitors for both endocrine and exocrine pancreas after brth. Proc Natl Acad Sci USA 105(50): 19915-19919. [PubMed]

77. Xu X, D'Hoker J, Stangé G, Bonné S, De Leu N, et al. (2008) Beta cells can be generated from endogenous progenitors in injured adult mouse pancreas. Cell 132(2): 197-207.[PubMed]

78. Kikugawa R, Katsuta H, Akashi T, Yatoh S, Weir GC, et al. (2009) Differentiation of COPASsorted non-endocrine pancreatic cells into insulin-positive cells in the mouse. Diabetologia 52(4): 645-652.[PubMed]

79. Bulotta A, Hui H, Anastasi E, Bertolotto C, Boros LG, et al. (2002) Cultured pancreatic ductal cells undergo cell cycle re-distribution and beta-cell-like differentiation in response to glucagon-like peptide-1. J Mol Endocrinol 29(3): 347-360.[PubMed]

80. Zhou J, Wang X, Pineyro MA, Egan JM (1999) Glucagon-like peptide 1 and exendin-4 convert pancreatic AR42J cells into glucagon- and insulin-producing cells. Diabetes 48(12): 2358-2366.[PubMed]

81. Zhou J, Pineyro MA, Wang X, Doyle ME, Egan JM (2002) Exendin-4 differentiation of a human pancreatic duct cell line into endocrine cells: involvement of PDX-1 and HNF3beta transcription factors. J Cell Physiol 192(3): 304-314.[PubMed]
82. Mashima $\mathrm{H}$, Shibata $\mathrm{H}$, Mine $T$, Kojima I (1996) Formation of insulin-producing cells from pancreatic acinar AR42J cells by hepatocyte growth factor. Endocrinology 137(9): 3969-3976.[PubMed]

83. Mashima H, Ohnishi H, Wakabayashi K, Mine T, Miyagawa J, et al. (1996) Betacellulin and activin A coordinately convert amylase-secreting pancreatic AR42J cells into insulin-secreting cells. J Clin Invest 97(7): 1647-1654. [PubMed]

84. Noguchi H, Xu G, Matsumoto S, Kaneto H, Kobayashi N, et al. (2006) Induction of pancreatic stem/progenitor cells into insulin-producing cells by adenoviralmediated gene transfer technology. Cell Transplant 15(10): 929-938.[PubMed]

85. Noguchi $\mathrm{H}$, Kaneto H, Weir GC, Bonner-Weir S (2003) PDX-1 protein containing its own antennapedia-like protein transduction domain can transduce pancreatic duct and islet cells. Diabetes 52(7): 1732-1737.[PubMed]

86. Kaitsuka T, Noguchi H, Shiraki N, Kubo T, Wei FY, et al. (2014) Generation of functional insulin-producing cells from mouse embryonic stem cells through $804 \mathrm{G}$ cell-derived extracellular matrix and protein transduction of transcription factors. Stem Cells Trans Med 3(1): 114-127.[PubMed]

87. Yatoh S, Dodge R, Akashi T, Omer A, Sharma A, et al. (2007) Differentiation of affinity-purified human pancreatic duct cells to beta-cell. Diabetes 56(7): 18021809.[PubMed]

88. Hoesli CA1, Johnson JD, Piret JM (2012) Purified human pancreatic duct cell culture conditions defined by serum-free high-content growth factor screening. PLoS One 7(3): e33999.[PubMed]

89. Lee J, Sugiyama T, Liu Y, Wang J, Gu X, et al. (2013) Expansion and conversion of human pancreatic ductal cells into insulin-secreting endocrine cells. Elife 2: e00940.[PubMed]

90. Kroon E, Martinson LA, Kadoya K, Bang AG, Kelly OG, et al. (2008) Pancreatic endoderm derived from human embryonic stem cells generates glucoseresponsive insulin-secreting cells in vivo. Nat Biotechnol 26(4): 443-452. [PubMed]

91. Chen S, Borowiak M, Fox JL, Maehr R, Osafune K, et al. (2009) A small molecule that directs differentiation of human ESCs into the pancreatic lineage. Nat Chem Biol 5(4): 258-265.[PubMed]

92. Nagaya M, Katsuta H, Kaneto H, Bonner-Weir S, Weir GC (2009) Adult mouse intrahepatic biliary epithelial cells induced in vitro to become insulin-producing cells. J Endocrinol 201(1): 37-47.[PubMed]

93. Tang DQ, Wang Q, Burkhardt BR, Litherland SA, Atkinson MA, et al. (2012) In vitro generation of functional insulin-producing cells from human bone marrow-derived stem cells, but long-term culture running risk of malignant transformation. Am J Stem Cells 1(2): 114-127.[PubMed] 